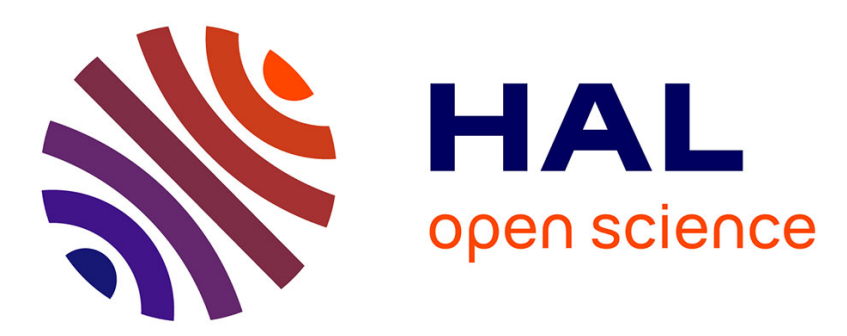

\title{
A new Device for Virtual or Augmented Underwater Diving
}

Christophe Domingues, Samir Otmane, Alain Dinis

\section{To cite this version:}

Christophe Domingues, Samir Otmane, Alain Dinis. A new Device for Virtual or Augmented Underwater Diving. IEEE Symposium on 3D User Interface (3DUI 2012), Mar 2012, Orange County, CA, United States. pp.141-142, 10.1109/3DUI.2012.6184201 . hal-00660882

\section{HAL Id: hal-00660882 https://hal.science/hal-00660882}

Submitted on 18 Jan 2012

HAL is a multi-disciplinary open access archive for the deposit and dissemination of scientific research documents, whether they are published or not. The documents may come from teaching and research institutions in France or abroad, or from public or private research centers.
L'archive ouverte pluridisciplinaire HAL, est destinée au dépôt et à la diffusion de documents scientifiques de niveau recherche, publiés ou non, émanant des établissements d'enseignement et de recherche français ou étrangers, des laboratoires publics ou privés. 


\title{
A new Device for Virtual or Augmented Underwater Diving
}

\author{
Christophe Domingues ${ }^{1}$, Samir Otmane ${ }^{1}$ and Alain Dinis ${ }^{2}$ \\ ${ }^{1}$ IBISC EA 4526- University of Evry, France \\ ${ }^{2}$ VirtualDive SAS, France
}

\begin{abstract}
The objective of this work is to recreate the sensorial conditions of scuba diving in the most frequented public aquatic spaces Beaches and Swimming pools. The version of the device included is autonomous, mobile and easily transportable by one person in a backpack. It can also be easily installed, equipped with GPS and wireless systems, and has positive buoyancy. Also, the possibility to integrate a component that may give a self-propelling capacity may be considered. In fact, by reducing the length of the anchoring cable, it will be possible to modify the depth of immersion. The device will be used at water surface as well as underwater using a tuba $(-40 \mathrm{~cm})$. Moreover, the device is equipped with one (can be upgraded for more) video camera pointing downwards. In fact, Augmented Reality contents combining actual underwater images with $3 \mathrm{D}$ animated images will be one of the preferred ways to use the device. Priority will be given to technical options leading to a "green" device, with renewable power consumption and built with recyclable materials.
\end{abstract}

KeYwords: Underwater diving, Augmented Reality, Virtual Reality, Device

IndeX Terms: K.5.1 [Multimedia Information Systems]: Artificial, augmented, and virtual realities I.3.7 [ThreeDimensional Graphics and Realism]: Virtual reality

\section{INTRODUCTION}

The introduction of virtual and mixed realities in aquatic leisure activities constitutes a technological rupture when compared with the status of related technologies. With the extension of Internet to underwater applications, the innovative character of the project becomes evident, and the impact of this development in the littoral and beach tourism may be considerable. Indeed, a new form of durable tourism will surge and beaches will evolve to become playgrounds for entertainment, knowledge and social intercourse. In fact, there are recent developments to extend the use of computers and computer components, such as the mouse, to underwater uses [1] [2] [3]. There is no example of an underwater-computerized display system conceived for existing swimming pools and for beach shores, associating computer functions, video gaming and multisensory simulations. The visualization - in immersion, of underwater contents through the web or integrating virtual, mixed and augmented reality, breaks new ground in multimedia applications and aims to change the nature of activities developed in the swimming pools and on the beaches.

\section{System Description}

The prototype presented in this paper is an ACER W500 x86 tablet running Windows 7 that is connected to various devices:

IBISC - Bâtiment Pelvoux 2, IUP

40 Rue de Pelvoux

CE1455 Courcouronnes 91020 Evry Cédex, France user interface device, GPS, sensors (thermometer, flow-meter) and a WIFI device. The prototype is using an evaluation support, which will be used to test the operating architecture in underwater conditions (see figures 1, 2 and 3).

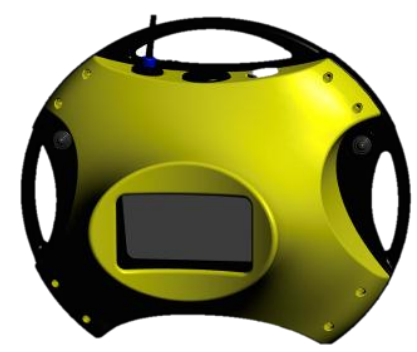

Figure 1. 3D model of the device

Two modules compose the prototype:

- Waterproof case which contains the tablet;

- Waterproof electronic case that is used to manage all connected devices.

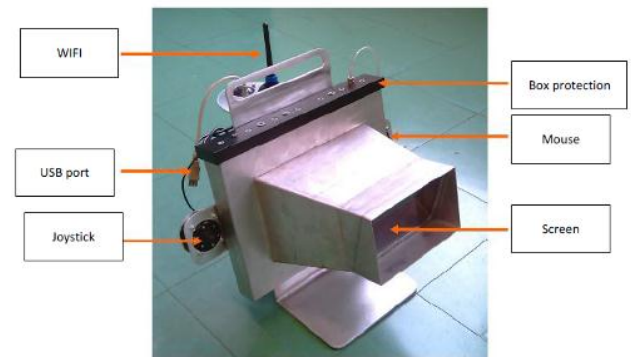

Figure 2. Prototype - Front view

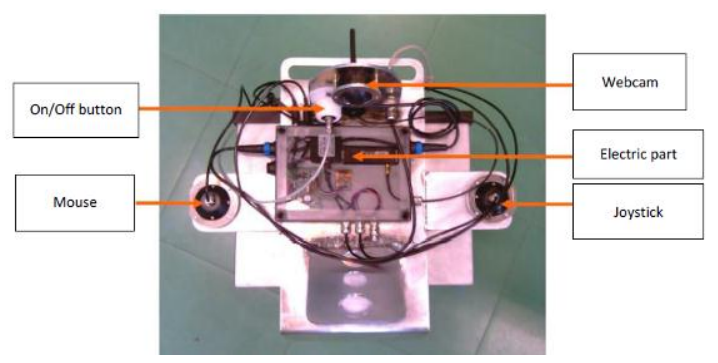

Figure 3. Prototype - Back view

To power the tablet, the user must press the white and black button located on the top of the device. A hydraulic system is used to transmit the movement of an actuator button in front of the on/off button of the tablet. To interact with the tablet, there are two joysticks on the left and right of the prototype. Each one is equipped with a center button for filling the function of a mouse click. The default configuration used is as follows (see Figure 4):

- $\quad$ Right Joystick: Mouse moves. The button is acting as a mouse left click;

\{firstname.lastname\}@ibisc.univ-evry.fr 
- Left joystick: Use to play games. It is acting as a joypad. However the central button is acting as the mouse right click;

- Flow meter: to measure the displacement of the device. It is acting as a z-joypad.

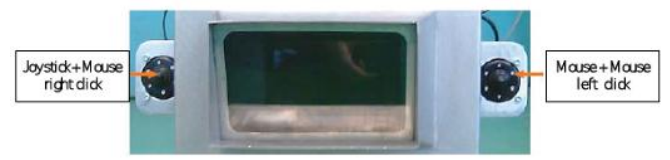

Figure 4. Joysticks device

\section{Content}

Many type of content is currently being developed for this device. We have decided to present a Virtual Reality (VR) and and an Augmented Reality (AR) content.

\subsection{Virtual Reality Content}

A virtual reality game has been developed that we call Nautilus Quest. Nautilus Quest aims to explore the underwater world of the Mediterranean in an entertaining and educational manner. The game can be installed on several devices allowing for multiplayer gaming. It offers three different missions simultaneously:

- Collection of waste (learn to respect the ocean);

- Underwater Photo Safari (discover the local flora and fauna);

- Search for treasures (fun missions).

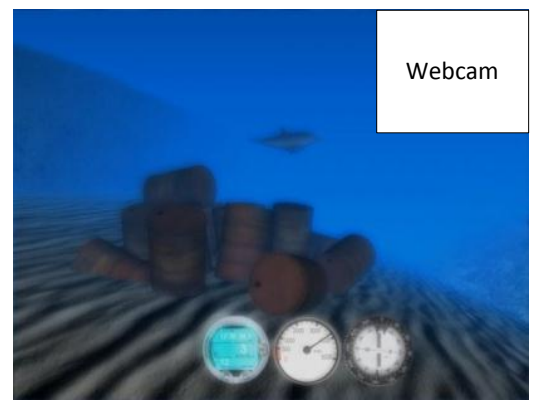

Figure 5. Nautilus Quest - The webcam allows the user to view his/her real trajectory on the sea or the swimming pool

\subsection{Augmented Reality Content}

AR Content is using AR markers on buoys recognized by the camera (using ARtoolkit [4]). Two scenarios have been set-up. The goal of the first one is to learn navigation signals. The diver/swimmer must follow a path illustrated by different AR buoys. Figure 6 illustrates the AR markers used to show the starboard or port signals.

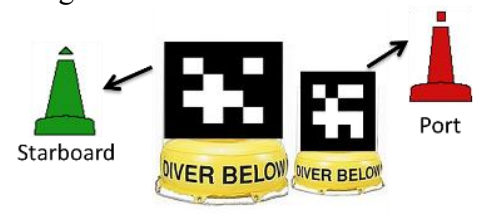

Figure 6. Augmented navigation buoys

The goal of the second scenario is to find a treasure, while buoys are located on the sea or in a swimming pool. However, to find the treasure, the player must first find the treasure key. To help the user, a virtual "fairy" character (as shown on the top right of Figure 7) can help him/her find the compass, which is a mandatory object to find the treasure. In fact, at the beginning of the game, the compass is not activated in the device, which makes it difficult to find the treasure and the key. When the diver finds the augmented compass buoy, the real compass and the map will be activated in the device.

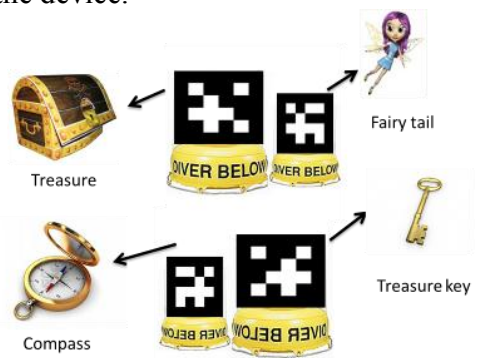

Figure 7. Augmented treasure game buoys

Those AR buoys can be ballasted and be used for diving trails with the device.

\section{Testing}

Tests have been performed in October 2011 in a French diving pit. Those tests were performed to detect potential waterproof problems (see Figure 8).

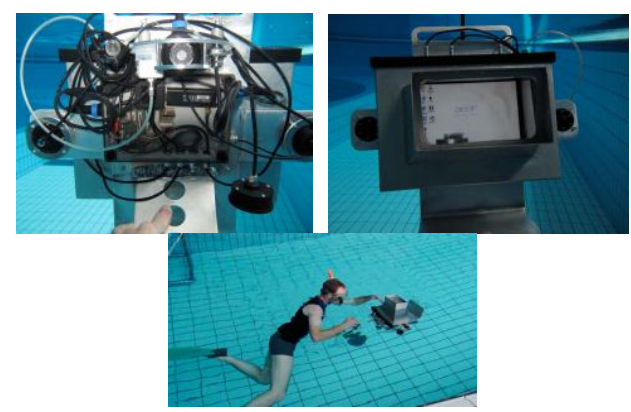

Figure 8. Prototype underwater testing - Back and front views

\section{Conclusion}

In this paper, we presented a work-in-progress. We are currently working on the assembly of the waterproof box in order to run tests as soon as possible. Other technological improvements are planned for the medium and long term, such as haptic joysticks, 3D monitors, sensors or "eye tracking" systems.

This project (Digital Ocean - FP7 262160) is a collaborative project funded through European Community's Framework Programme FP7.

\section{References}

[1] A. Dinis, N. Fies, N. Cheaib, S. Otmane, M. Mallem, A. Nisan, J.M. Boi. DIGITAL OCEAN: A National Project for the creation and distribution of Multimedia Content for Underwater Sites. Proc. of the 14th International Conference on Virtual Systems and MultiMedia, Dedicated to Digital Heritage, VSMM'08, pages 389396, Limassol Cyprus, October 2008.

[2] R. L. Ashok and D. P. Agrawal. Next-Generation Wearable Networks. In IEEE Computer 36, 31-39, November 2003.

[3] Bruce Macdonald. A haptic interface for mobile devices. In Proceedings of the 17th Australia conference on Computer-Human Interaction... OZCHI '05, Narrabundah, pages 1-3, 2005.

[4] M. Billinghurst, A. Cheok, S. Prince, H. Kato. Real World Teleconferencing. In IEEE Computer Graphics and Applications, Vol 22, No 6, pages 11-13, Nov/Dec 2002 